\title{
Why State and Federal Officials Should Consider Offering Financial Literacy Training to Those About to Be Released from Correctional Institutions
}

\author{
Ken Galchus ${ }^{1}$ \\ ${ }^{1}$ Department of Economics and Finance, University of Arkansas at Little Rock, USA \\ Correspondence: Ken Galchus, Professor of Economics, Department of Economics and Finance, University of \\ Arkansas at Little Rock, USA
}

Received: August 4, 2015

Accepted: August 25, 2015

Online Published: September 4, 2015

doi:10.5430/ijfr.v6n4p60

URL: http://dx.doi.org/10.5430/ijfr.v6n4p60

\begin{abstract}
There have been numerous studies over the years which have attempted to measure the financial literacy level of high school students, college students, and Americans in general. As opposed to the groups listed above, this article looks at the financial capability of prisoners in various Arkansas' correctional institutions. The idea is that if people, upon their release from prison, don't know such basic things as how to open a checking/savings account, don't know how to balance a checkbook, and don't realize the importance of saving for retirement, they are being set up for failure from the beginning. Using results from a 43 question financial capability survey filled out by 299 male inmates in Arkansas' correctional facilities, and comparing them to results for 211 Arkansas' males interviewed as part of the recent Financial Institute Regulatory Authority's (FINRA) 2012 National Financial Capability Study, shows that the financial capability of inmates is even lower than that of males in the general population (which is already low). The conclusion is that there should be financial literacy training as part of prerelease programs designed to get inmates ready for reentry back into society, and this, in turn, may help to reduce the recidivism rate.
\end{abstract}

Keywords: financial literacy, financial literacy training in prisons, reentry programs, wealth accumulation

\section{Introduction}

Over the years there have been studies designed to measure the level of financial literacy of high school students (Mandell, 2008), college students (Chen \& Volpe, 1998), and U.S. adults (FINRA Investor Education Foundation, 2013). These studies generally show that the level of financial literacy is relatively low among the people in these groups. And this is just a sample of the research in this area. Moreover, research in this area is not just confined to the U.S. Recently released PISA (Programme for International Student Assessment) results (OECD, 2014) examined 15 year old students' performance in a financial literacy assessment in 18 countries. Top scorers included China and Belgium, with the U.S. and Russia in the middle of the pack.

In a departure from the normal groups (high school students, college students, etc.) studied in this area, Galchus (2014), in a recent article looked at the level of financial literacy of a sample of prisoners in Arkansas' correctional institutions. In this article, Galchus looked at preliminary results for a sample of 162 male prisoners, and compared their financial capability, where possible, with survey findings from the Financial Institute Regulatory Authority's (FINRA), 2012 National Financial Capability Study (2013). This study was designed to measure the financial capability level of Americans, and can be used as a benchmark against which one can measure the level of financial literacy of inmates in Arkansas' correctional institutions. The prisoner survey data were generated as part of the ongoing Prisoner Financial Literacy Project at the University of Arkansas at Little Rock. The preliminary results showed that, for example, on several financial literacy questions, prisoners' knowledge was even below that of the general (FINRA) population (which is already low). As an example, only $31.5 \%$ of the prisoners surveyed knew that if you were to put $\$ 100$ in a savings account paying 5\% interest annually that you would have $\$ 105$ at the end of one year. Seventy five percent of the people in the national FINRA survey knew the correct answer to this question. Other results showed that a relatively high percentage of prisoners had engaged in non-bank borrowing before their incarceration, and that over $25 \%$ had never had a checking or savings account. Thus, Galchus concluded that the 
level of financial literacy of prisoners is low relative to that of the general population, and, thus, that financial literacy training in correctional institutions would be a useful addition to reentry programs. (Note 1)

The rationale behind this study (Galchus, 2014) was that if people being released from prison are financially illiterate (e.g. don't know such things as how to open a checking/saving account, don't know how to balance a checkbook, and don't understand the importance of saving for retirement), we, as a society, are setting them up for failure from the beginning, and this can only have a negative effect on the recidivism rate. That is, job training, for example, within correctional institutions so that ex-offenders can get a job once they are released from prison will provide former prisoners with an income. But an income will only meet the short term needs of an individual (Martin, 2011). This would become obvious quickly to an ex-offender if he lost his job, or became ill and could no longer work. Rather than focusing on a job with a steady income, the wider focus of prerelease programs in correctional institutions should be on wealth (or asset) accumulation. Wealth can tide an ex-offender over if he were laid off from his job, or could not work for a period of time due to a serious illness. In other words, the accumulation of wealth will meet the long term needs of an individual. However, if an ex-offender is financially illiterate, he will have a tough time building the necessary wealth to meet his long term financial needs. Moreover, recent empirical research does show a connection between financial literacy and wealth accumulation. Behrman, Mitchell, Soo and Bravo (2012) find that there is a positive and statistically significant link between the level of financial literacy and wealth accumulation. Similar results are reported by Rooij, Lusardi, and Alessie (2012). And so based on all this evidence, Galchus argued that there is a need for financial training in correctional institutions.

\section{Methodology}

The purpose of the present study is to update Galchus' work by analyzing the complete sample of 299 prisoner financial literacy surveys, instead of just the preliminary sample of 162 surveys that were available to him at the time. Also, whereas Galchus (2014) compared prisoner financial literacy responses, to national FINRA data, the present study is able to compare prisoner responses with answers for the sample of 211 Arkansas males surveyed as part of the 2012 FINRA study. And so this will provide a much more accurate benchmark against which to measure the level of Arkansas' inmates' level of financial literacy.

As reviewed by Galchus (2014) in his article, data for the ongoing Prisoner Financial Literacy Project at the University of Arkansas at Little Rock, were generated by surveying prisoners (or insiders, as they liked to be called) at the Arkansas' Department of Correction facilities within a 50 mile radius of Little Rock. Prisons in other parts of the state were not visited due to logistical reasons. Data were collected from September, 2013 through March, 2014 by visiting prison units in Wrightsville, Pine Bluff and Malvern. Inmates were told that their participation in the survey was entirely voluntary, and that their survey responses would be completely anonymous. During multiple visits to these prisons, inmates, in reentry classes, were asked to fill out the financial capability survey. The reason why this study concentrated on male inmates, is that it was these facilities (as opposed to those housing female inmates) that were most readily accessible to the researchers.

The financial literacy survey (provided in the appendix) that insiders were asked to complete contains 43 questions. The survey instrument includes general demographic questions, and questions relating to the offender's financial capability as well as his criminal history. General demographic questions requested such things as the respondent's age, ethnicity, and marital status. The survey instrument's focus on financial capability had two components. The first looked at the difference in the level of financial knowledge (questions 5, 21, and 22 on the survey) between inmates and the 211 Arkansas males in the 2012 FINRA survey. (Note 2) The second focused on differences between prisoners and Arkansas' males' financial history and practices, such as experience with traditional banking institutions and predatory lenders.

\section{Discussion of Results}

Demographic data comparing prisoners to the sample of Arkansas males which were part of the FINRA survey show that prisoners are younger ( 34.3 years vs. 51.5 years), and mainly unmarried $(22.5 \%$ vs. $61.0 \%)$. Approximately, $55.9 \%$ of the prisoners sampled were nonwhite compared to a nonwhite percentage of $20.4 \%$ for males in the FINRA sample. Table 1 shows the percentage of positive responses on the survey questions for inmates compared to the percentage of positive responses on a similar set of questions for the FINRA sample of 211 male Arkansans. It should be noted at the outset that the questions on the Arkansas inmate survey are usually phrased as "Have you ever had a......?." or "Have you ever checked...?.", because of the insiders' incarceration. On the FINRA survey, however, questions are phrased as, "Do you have a checking account (or savings account?") or "Do you own a car?", and so the questions on the two surveys are phrased slightly differently. For the purposes of this study, however, the 
researcher felt that the questions asked were similar enough so that comparisons could be made between both sets of data.

For convenience, questions on the survey are broken up into four categories: 'Mainstream Banking', 'Financial Planning', 'Predatory Lending', 'Financial Knowledge' and are listed that way in Table 1. Statistical results are reported for each question to determine whether there is a statistically significant difference in the percentage of positive responses between inmates and males in the FINRA sample. The legend at the bottom of the table shows the meaning of $* * *, * *$, and $*$. For example, ${ }^{* * *}$ indicates that the percentage difference is statistically significant at the .001 level.

Table 1. Financial capability comparison between Arkansas insiders and the FINRA sample (211) of Arkansas males

\begin{tabular}{lll}
\hline Mainstream Banking & Insiders & $\begin{array}{l}\text { Sample of } \\
\text { Arkansas Males }\end{array}$ \\
\hline Have/Ever Had a Checking Account? & $72.97 \%^{* * *}$ & $89.60 \%$ \\
\hline Have/Ever Had a Savings Account? & $72.8 \%^{*}$ & $66.35 \%$ \\
\hline Have/Ever Had a Debit Card? & $60.9 \%^{* *}$ & $72.50 \%$ \\
\hline Have/Ever Had a Credit Card? & $43.8 \%^{* * *}$ & $72.50 \%$ \\
\hline \# of Credit Cards Had/Have & $0.86^{* * *}$ & 1.68 \\
\hline $\begin{array}{l}\text { Non-banked (Never Had a Checking or Savings } \\
\text { Account) }\end{array}$ & $16.8 \% \%^{* * *}$ & $8.00 \%$ \\
\hline
\end{tabular}

Financial Planning

Do You Have Life Insurance? $\quad 24.8 \% * * * \quad 57.40 \%$

Ever Determined the Amount of Money Needed for $11.1 \% * * * \quad 39.20 \%$

Retirement?

Ever Checked Your Credit Score? $\quad 36.2 \% * \quad 45.97 \%$

\section{Predatory Lending}

\begin{tabular}{lll} 
Ever Used a Payday Lender? & $22.5 \% * * *$ & $11.11 \%$ \\
\hline Ever Used a Pawn Shop? & $75.42 \% * * *$ & $21.90 \%$ \\
\hline Ever Used 'Rent to Own Store'? & $45.12 \% * * *$ & $11.11 \%$ \\
\hline Ever Paid a Bill With a Money Order? & $59.52 \% * * *$ & $26.07 \%$
\end{tabular}

\begin{tabular}{lll}
\hline Financial Knowledge & & \\
\hline Interest Rate Ques. (\#5) - \% Correct Ans. & $33.11 \% * * *$ & $79.62 \%$ \\
\hline $\begin{array}{ll}\text { Inflation Rate Ques. (\#21) - \% Correct Ans. } \\
48.3 \% * * *\end{array}$ & $73.00 \%$ \\
\hline $\begin{array}{l}\text { Stock/Mutual Funds Ques. (\#22) - } \\
\text { \% Correct Ans. }\end{array}$ & $36.9 \% * * *$ & $55.00 \%$ \\
\hline $\begin{array}{l}\text { Financial Knowledge Scale (Combining Results from } \\
\text { Previous Three Questions) }\end{array}$ & $1.19^{* * *}$ & 2.08 \\
\hline
\end{tabular}

$* * * \mathrm{p}<.001 ; * * \mathrm{p}<.01 ; * \mathrm{p}<.05$

In reviewing the results for Table 1, one can see that, on an overall basis, insiders fare poorly, in terms of financial capability, compared to males in the FINRA sample. For example, for the 'Mainstream Banking' category, a higher percentage of males in the general population have a checking account, credit card, and debit card, as compared to the percentage of insiders who have ever had one of these items. Also, the percentage of insiders who are 'unbanked' is higher than that for the sample of males in the general population, as the previous results would suggest. The fact that a lower percentage of males in the general population have a savings account may indicate that they are more 
financially savvy than insiders given the relatively low interest rate paid on funds in savings accounts in the last few years. This difference, however, is not statistically significant.

In the 'Financial Planning' category, a greater percentage of males in the general population (as compared to insiders) have life insurance, determined their retirement needs, and checked their credit score at some point. Similarly, in the 'Predatory Lending' category, a greater percentage of insiders have used payday lenders, pawn shops, 'rent to own stores', and have paid bills with money orders as compared to males in the FINRA survey.

Finally, in the 'Financial Knowledge' section, the percentage of correct responses by insiders for the interest rate (Note 3), inflation (Note 4), and risk (Note 5) questions can be compared with the results for a comparable set of questions asked of Arkansas males in the FINRA study (2012 National Financial Capability State-by-State Survey Instrument 2013). One can clearly see that, on all three financial literacy questions, Arkansas males in the FINRA survey had a greater percentage of correct answers than insiders. These differences are statistically significant as are almost all differences reported in Table 1. The last item in the 'Financial Knowledge' section is a composite of answers on the previous three questions, and as one can see this difference is statistically significant also. This indicates that males in the general population have a greater knowledge of personal finance (at least with respect to the material covered in these three questions) than insiders.

\section{Summary and Implications}

The evidence discussed in this paper strongly suggests the need for financial literacy training for inmates about to be released from correctional institutions. This becomes very obvious when reviewing the results from Table 1 that show that the financial capability of insiders in Arkansas' correctional institutions is relatively low in contrast to that of a sample of males in the general population. Releasing former prisoners back into society who have little or no background in personal finance sets them up for failure from the very start, and this, of course can affect the recidivism rate. This is not to say that other aspects of reentry programs, such as job training, are not useful. But the results shown here demonstrate that financial literacy training should be an integral part of any reentry program.

The logical extension of the results found above suggests the creation of a financial literacy program for those about to be released from correctional institutions. A comprehensive financial literacy program could serve as a model for other states' correctional institutions, and for federal facilities as well. The cost of developing such a program would be minimal, since there are numerous resources available on the Internet that could assist in the development of such a program. There would be a cost, however, in having qualified people offer financial literacy workshops in penal institutions. However, there is also a definite cost to society of having a high recidivism rate.

\section{Acknowledgements}

The author wishes to acknowledge the assistance of Andy Terry, Mark Funk, Tim Brown, and Marc Glidden, all of whom worked on this project at one time or another. The author also wishes to thank the University of Arkansas at Little Rock's Institute of Race and Ethnicity that provided funding for this project.

\section{References}

Behrman, J., Mitchell, O., Soo, C., \& Bravo, D. (2012). Financial literacy, schooling, and wealth accumulation. American Economic Review, 102, 300-304. http://dx.doi.org/10.1257/aer.102.3.300

Chen, H., \& Volpe, R. (1998). An analysis of personal financial literacy among college students. Financial Services Review, 7, 107-128. http://dx.doi.org/10.1016/S1057-0810(99)80006-7

FINRA Investor Education Foundation. (2013). Financial capability in the United States: Report of findings from the 2012 National Financial Capability Study. Retrieved from http://www.usfinancialcapability.org/downloads/NFCS_2012_Report_Natl_Findings.pdf

FINRA Investor Education Foundation. (2013). 2012 National financial capability state-by-state survey instrument. Retrieved from http:/www.usfinancialcapability.org/downloads/NFCS_2012_State_by_State_Qre.pdf

Galchus, K. (2014). The case for financial literacy training in correctional Institutions. International Research Journal of Applied Finance, 6, 781-788. Retrieved from https://irjaf.com/View_Articles.html

Mandell, L. (2008). Financial literacy of high school students. In J. Xiao (Ed.), Handbook of consumer finance research (pp. 163-183). New York: Springer. http://dx.doi.org/10.1007/978-0-387-75734-6_10

Martin, L. (2011). Debt to society: Asset poverty and prisoner reentry. Review of Black Political Economy, 38, 131-143. http://dx.doi.org/10.1007/s12114-011-9087-1 
OECD. (2014). PISA 2012 Results: Students and money. Retrieved from http://www.oecd.org/pisa/keyfindings/pisa-2012-results-volume-vi.htm

Van Rooij, M., Lusardi, A., \& Alessie, R. (2012). Financial literacy, retirement planning, and household wealth. Economic Journal, 122, 449-478. http://dx.doi.org/10.1111/j.1468-0297.2012.02501.x

\section{Notes}

Note 1. Reentry programs are designed to get the prisoner ready for release back into society.

Note 2. There were similar 'financial knowledge' questions on the FINRA survey.

Note 3. If you put $\$ 100$ in a bank paying 5\% interest, how much will you have in your account after one year?

Note 4. Imagine that the interest rate on your savings account was $1 \%$ per year, and inflation was $2 \%$ per year. After 1 year, how much would you be able to buy with the money in this account? (More than today/Exactly the same/Less than today/Don't know))

Note 5. Buying a single company's stock usually provides a safer return than a stock mutual fund (True/False/Don't know)

Appendix. Survey of Financial Knowledge

1. Have you ever had a credit card? Yes No

2. If so, how many?

3. Have you ever filed for bankruptcy? Yes No

4. Have you ever made a household budget? Yes

No

5. If you put $\$ 100$ in a bank account paying 5\% interest, how much will you have in your account after one year?

6. Have you ever owned your own home? Yes

No

7. Have you ever had a home mortgage? Yes

No

8. Have you ever owned a car? Yes

No

9. Have you ever had a car loan? Yes

No

10. Have you ever had a savings account? Yes No

11. Have you ever had a checking account? Yes No

12. Have you ever borrowed money from a 'payday lender'? Yes No

13. Have you ever figured out, how much money you will need for retirement? Yes No 
14. Do you have any money saved for retirement? Yes

No

15. Have you ever checked your credit report? Yes

No

16. Have you ever checked your credit score? Yes

No

17. Have you ever used online banking (to pay bills, to check the amount in your savings/checking account, etc)? Yes

No

18. Do you have life insurance? Yes

No

19. Have you ever used a pawn shop? Yes

No

20. Have you ever used a rent-to-own store? Yes

No

21. Imagine that the interest rate on your savings account was $1 \%$ per year, and inflation was $2 \%$ per year. After 1 year, how much would you be able to buy with the money in this account?

More than today

Exactly the same

Less than today

Don't know.

22. Buying a single company's stock usually provides a safer return than a stock mutual fund.

True

False Don't know

23. What was your annual income at your last job?

Have Never Worked
$\$ 0-\$ 10,000$
$\$ 10,0001-\$ 15,000$
$\$ 15,0001-\$ 20,000$
$\$ 20,0001-\$ 30,000$
$\$ 30,0001-\$ 40,000$
$\$ 40,0001-\$ 50,000$
$\$ 50,0001-\$ 75,000$
$\$ 75,000$ and above

24. If you lose your credit card, what is your maximum liability?

$\$ 0$

$\$ 50$ $\$ 100$

I'm liable for everything that someone might charge on my card. 
25. Your take home pay from your job will be less than the total amount that you earn.

Which of the following items will be taken out of your pay check?

Federal Income Tax

Social Security Tax

Medicare Tax

all of these

26. David just found a job with a take home pay of $\$ 2000$ per month. He spends $\$ 1850$

per month and so saves $\$ 150$ per month. How many months will it take him to save

$\$ 600$ ?

1 month
2 months
3 months
4 months
4 none of these

27. On a scale from 0 to 7 , where 0 means none, and 7 means very high, how would you rate your overall financial knowledge?

$$
\begin{array}{llllllll}
0 & 1 & 2 & 3 & 4 & 5 & 6 & 7
\end{array}
$$

28. In the past, have you paid bills with money orders? Yes

No

29. In the past, have you cashed checks at a supermarket or grocery store?

$$
\text { Yes }
$$

No

30. Have you ever had a debit card? Yes

No

31. What is your age $?$

32. Are you Male

Female $?$

33. Would you describe yourself as:

American Indian/Native American

Asian

Black/African American

Hispanic/Latino

White/Caucasian

Pacific Islander

Other 
34. Are you Married , Divorced , Single/Never Married

Widow/Widower ?

35. What was your education level prior to your current imprisonment? (Check the appropriate line)

Did Not Complete High School

High School/GED Graduate

Some College

College Graduate

Post Graduate Education

36. Have you served time before? Yes

No

37. If your answer to the last question was 'Yes', how many times have you been in a correctional institution before this?

38. How old were you the first time you were incarcerated?

39. How long is your current sentence?

40. How much of your current sentence have you already served?

41. In what city or county were you living at the time of your current conviction?

42. What offense(s) are you currently serving time for $?$

43. What was your annual household income prior to your imprisonment?

$\begin{array}{cc}\$ 0 & -\$ 10,000 \\ \$ 10,0001-\$ 15,000 \\ \$ 15,0001-\$ 20,000 \\ \$ 20,0001-\$ 30,000 \\ \$ 30,0001-\$ 40,000 \\ \$ 40,0001-\$ 50,000 \\ \$ 50,0001-\$ 75,000 \\ \$ 75,000 \text { and above }\end{array}$

